\title{
Improved Livelihoods - A Case Study from Asian Paints Limited
}

\author{
Mukund D. Patil, * Suhas P. Wani, Kaushal K. Garg and \\ RAJESH NUNE
}

International Crops Research Institute for the Semi-Arid Tropics, Patancheru, India

\begin{abstract}
Asian Paints Limited and International Crops Research Institute for the Semi-Arid Tropics (ICRISAT) collaborated to improve rural livelihoods through integrated watershed development programme. Six villages in Patancheru mandal of Medak district, Telangana, India covering an area of 7143 ha were selected in consultation with the local community for Asian Paints Limited-ICRISAT watershed. The prime mitigation strategy for addressing water scarcity was initiated in the project by rainwater harvesting, efficient use of available water resources and recycling of grey water. Science-led interventions including soil test-based nutrient management, and improved crop cultivars and management practices were introduced for improving crop productivity. Rainwater harvesting structures of a total water storage capacity of $34,000 \mathrm{~m}^{3}$ were utilized for groundwater recharge. Based on the observation, estimated groundwater recharge due to check-dams with total storage capacity of $12,700 \mathrm{~m}^{3}$ during 2016 was $91,000 \mathrm{~m}^{3}$. The improved agronomic practices demonstrated in farmers' fields have shown $30-50 \%$ increase in grain yield.
\end{abstract}

\subsection{Background}

\subsubsection{Why? Problem statement}

Water, food and energy securities are emerging as increasingly important issues for the world. Especially, rainfed agriculture in arid and semiarid regions is experiencing moderate to severe water shortage and land degradation, due to the simultaneous effects of increasing food demand, industrialization and urbanization. The complexity of the problem is further increased by factors such as population rise, rapid and unplanned urbanization, change in cropping pattern towards water intensive cash crops, change of food preference towards water-intensive food products such as dairy and meat, and climate change.

For India, agriculture is the single largest sector, which provides employment to over $65 \%$ population, but at low net returns per hectare of cultivated land. The declining or low agricultural productivity is also affecting environmental sustainability as there is mismanagement of soil and water resources along with the negligence of local strategies. These trends however, showed increase in total agricultural production but decline in water productivity and other ecosystem services due to inefficient water use.

* Corresponding author: m.patil@cgiar.org 
If such trends continue, the system may lose its resilience ability and will be vulnerable to further degradation. Thus, it is necessary to strengthen the ecosystem services through natural resource management with people's participation in dryland areas.

\subsubsection{Integrated water resource management approach}

Watershed is a natural entity and comprises different types of land use from where rainwater is drained through a common outlet (lake, river) and therefore, can vary from several ha to 1 million ha. However, it is also a sociopolitical-ecological entity, which plays a crucial role in determining food, social and economic security and provides life support services to rural people (Wani et al., 2008). These watersheds provide various ecosystem services in uplands and the generated inflow supports downstream ecosystem. The holistic management of natural resources have shown greater resilience of crop income during the drought-like scenarios too. For example, while the share of crops in household income declined from $44 \%$ to $12 \%$ in the non-watershed project villages, crop income remained largely unchanged from $36 \%$ to $37 \%$ in the watershed village (Wani et al., 2009).

Integrated watershed management approach proved to be the suitable strategy for achieving holistic development in these regions through collective action (Wani et al., 2003). The very purpose of the watershed development programmes is to reduce water related risks in rainfed agriculture by improving the local soil-water balance by implementing both in-situ and ex-situ interventions. Since water and soil are important components of agricultural development, proper management of these resources is crucial to build the resilience of these systems to cope with varying climatic risks and to improve livelihoods. The International Crops Research Institute for the Semi-Arid Tropics (ICRISAT), Patancheru, Telangana, India has established model watersheds as learning sites for integrated watershed management programme in various agroclimatic regions of India. On similar grounds, Asian Paints Limited, Patancheru requested ICRISAT to develop an action site at their Patancheru works in Sanga Reddy district.

\subsubsection{Objectives}

The overall goal of this initiative is to increase agricultural productivity and improve the livelihoods of rural poor in fragile dryland areas on a sustainable basis by enhancing the impact of integrated watershed management programmes through capacity building initiatives using site of learning in low-rainfall agroecoregions. The specific goal of this initiative is to enhance the water resources availability (surface and groundwater), water productivity, income and livelihood in the selected villages of Patancheru mandal, Sangareddy district in Telangana. The objectives of the initiative are:

- To establish a 'Model Site of Learning' in Sangareddy district for demonstrating the potential of rainfed areas by adopting integrated water resource management approach.

- To enhance the water resource availability and its use efficiency through low-cost waterharvesting structures and to enhance capacity of existing water harvesting structures.

- To enhance agricultural productivity through land, water and nutrient management interventions.

- To build capacity of the farmers in the region for improving rural livelihoods through knowledge sharing and dissemination.

\subsubsection{Site selection}

Asian Paints Limited requested ICRISAT to select a project site in the vicinity of their factory in Patancheru mandal. The Patancheru mandal lies between $78.14^{\circ}$ to $78.351^{\circ}$ and $17.467^{\circ}$ to $17.624^{\circ}$ in Sangareddy district of Telangana state. Figure 6.1 shows Patancheru mandal and identified village locations (southwest) for the proposed watershed interventions. Field visits were conducted in four (north, east, west and southwest) directions to select villages for watershed (Fig. 6.1). ICRISAT team interacted with farmers during field visits to understand the farming system. Land resources in eastern villages were degraded due to high industrialization and real estate business. Agricultural land area in western villages decreased drastically due to groundwater pollution. In northern villages, only the area under tank irrigation is dominating as each village has two big water tanks. The rainfed area in southwestern villages is becoming fallow due to 


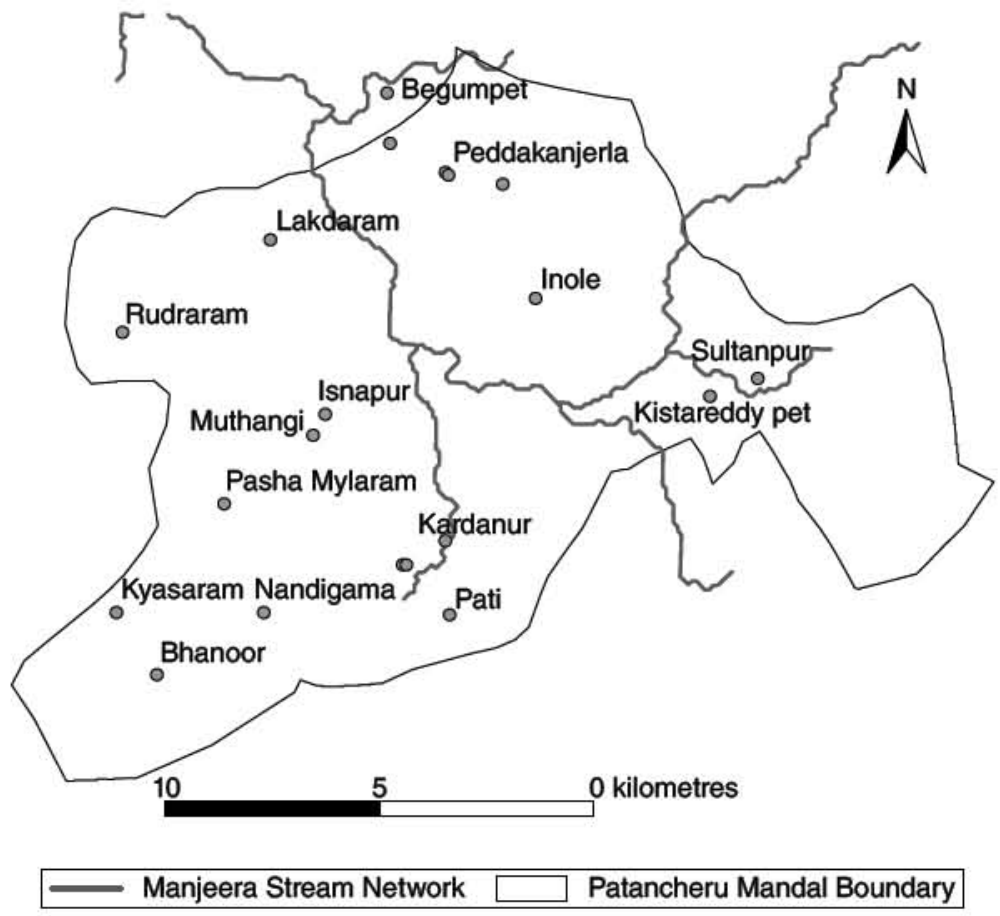

Fig. 6.1. Villages visited for selection of a site for the watershed project in Patancheru mandal, Sanga Reddy district, Telangana.

scarcity of surface and groundwater resources. The southwest region of Patancheru mandal (Bhanoor, Kyasaram, Nandigama, Kardanur, Pati and Ghanapur villages) had potential for implementing watershed interventions to enhance water resources availability, agricultural productivity and income.

\subsubsection{Site specification}

The project villages are located in and around Asian Paints Limited, Patancheru. Six villages were selected for implementation of watershed activities. The selected villages, covering a 7143 ha geographic area, are located $9 \mathrm{~km}$ west of ICRISAT campus. The rainfed area in these villages is $84 \%$ of total cultivable area while irrigated area is $9 \%$ and fallow land is $6 \%$ (Table 6.1). The main sources of irrigation are bore well and open well. Out of 4659 households, $56 \%$ households are small and marginal farmers, $8 \%$ are landless, and $34 \%$ are medium and large farmers (Table 6.2). Major crops in selected villages are maize, paddy, pigeonpea, cotton, sorghum and vegetables. Livestock is also a major component for livelihoods in these villages. Buffalo, sheep and goats constitute the major population of livestock (Table 6.3).

\subsection{Baseline Situation}

A primary household baseline survey was conducted from representative sample farmers ( 534 households) in the watershed villages. Information on socioeconomic status, area allocation under different crops, average productivity levels and prices, water utilization pattern at household and farm level, accessibility to credit, etc. was collected and summarized. The household data collected will be used as 'benchmark values' for monitoring the project progress over a period of time. The project impact assessment studies if any could be undertaken in future using baseline information. Overall, the comprehensive baseline report also helps in identifying major constraints and devising suitable strategies in 
Table 6.1. Land use pattern in selected watershed villages in Patancheru mandal, Telangana, India. From: Mandal Panchayat of Patancheru mandal, 2015.

\begin{tabular}{lcccccr}
\hline Village & Irrigated (ha) & Rainfed (ha) & $\begin{array}{c}\text { Fallow } \\
\text { land (ha) }\end{array}$ & $\begin{array}{c}\text { Common } \\
\text { property } \\
\text { resource (ha) }\end{array}$ & $\begin{array}{c}\text { Industrial } \\
\text { use (ha) }\end{array}$ & Total (ha) \\
\hline Pati & 82 & 442 & 38 & 32 & 202 & 796 \\
Bhanoor & 93 & 842 & 44 & 130 & 414 & 1523 \\
Kyasaram & 86 & 640 & 32 & 64 & 142 & 964 \\
Kardhanur & 54 & 422 & 42 & 24 & 140 & 682 \\
Ghanapur & 96 & 740 & 52 & 96 & 268 & 1252 \\
Nandigama & 90 & 1264 & 102 & 110 & 360 & 1926 \\
Total & 501 & 4350 & 310 & 456 & 1526 & 7143 \\
\hline
\end{tabular}

Table 6.2. Landholdings in selected watershed villages in Patancheru mandal, Telangana, India. From: Gram Panchayats of respective villages, 2015.

\begin{tabular}{lcrcccr}
\hline & \multicolumn{7}{c}{ No. of households } \\
\cline { 2 - 7 } Village & Large & Medium & Small & Marginal & Landless & Total \\
\hline Pati & 8 & 72 & 280 & 302 & 62 & 724 \\
Bhanoor & 22 & 602 & 220 & 355 & 149 & 1348 \\
Kyasaram & 14 & 222 & 204 & 248 & 64 & 752 \\
Kardanur & 4 & 42 & 122 & 120 & 28 & 316 \\
Ghanapur & 12 & 124 & 212 & 248 & 46 & 642 \\
Nandigama & 18 & 412 & 252 & 148 & 47 & 877 \\
Total & 78 & 1474 & 1290 & 1421 & 396 & 4659 \\
\hline
\end{tabular}

Table 6.3. Livestock population (numbers) in selected villages of watershed in Patancheru mandal, Telangana, India. From: Mandal Panchayat of Patancheru mandal, 2015.

\begin{tabular}{lccccr}
\hline Village & Cow & Buffalo & Bullock & $\begin{array}{l}\text { Others (goat, } \\
\text { sheep, etc.) }\end{array}$ & Total \\
\hline Pati & 2 & 129 & 12 & 312 & 455 \\
Bhanoor & 18 & 180 & 24 & 280 & 502 \\
Kyasaram & 8 & 160 & 12 & 160 & 340 \\
Kardanur & 4 & 45 & 10 & 80 & 139 \\
Ghanapur & 8 & 142 & 12 & 265 & 427 \\
Nandigama & 12 & 168 & 24 & 242 & 446 \\
Total & 52 & 824 & 94 & 1339 & 2309 \\
\hline
\end{tabular}

the pilot site and district as a whole. The key findings from baseline survey are discussed.

\subsubsection{Crop production}

\section{Cropping pattern}

Maize is the major crop under cultivation across all sample villages followed by paddy and cotton. Rabi (post-rainy season) area constitutes nearly $4 \%$ of the rainy season area and chickpea is the predominant crop cultivated during the season. The cultivable area under summer is very low and leafy vegetables are grown during the season. This shows the dependency of farmers on rainfall for their livelihood and if irrigation is assured the remaining $96 \%$ of the land can be brought under cultivation. 


\section{Crop yield}

The crop productivity data was collected from farmers on one year recall basis. The average productivity of crops is almost same across the villages with marginal variations. With average yield less than $1000 \mathrm{~kg} / \mathrm{ha}$, cotton is the most affected crop due to pest infestation across the villages.

\section{Fertilizer usage}

High utilization of urea was observed for cotton and maize. In addition to urea and diammonium phosphate, complex fertilizers were administered to cotton for higher returns. This exposes the risk of soil degradation and economic returns in cotton cultivation. Very few farmers reported use of micronutrients across the crops, which necessitates the need for educating the farmers on importance of micronutrient application for better growth and yield of crops.

\section{Incidence of insects and diseases}

Nearly $25 \%$ of the crops are getting infested with pests incurring an economic loss to farmers. Large-scale cultivation of high-yielding varieties and excessive use of nitrogenous fertilizers may further aggravate the incidence of pests. Farmers need to be educated on integrated pest management along with optimum utilization of fertilizers.

\section{Economics of different crop enterprises}

Among all crops, pigeonpea realized highest market price due to shortage of supply in the market. Majority of farmers complained of falling prices as cotton, paddy, maize and sorghum realized lesser price than the minimum support price announced by Government of India. Maize exhibited better benefit-cost ratio followed by pigeonpea, paddy and chickpea crops. Farmers were able to cover the variable costs of sorghum and recovered costs marginally. Cotton performed very badly among all crops in the study villages. Farmers were just able to recover their investments because of low productivity and higher costs of cultivation per acre.

\subsubsection{Household income}

The average household income of the pooled sample household was ₹162,000 per annum.
Around $40 \%$ of the total household income was contributed by agriculture, followed by salaried work $(27 \%)$ and daily wage income $(19 \%)$. Government development programmes, rentals from land and machinery, business and others together accounted for $14 \%$ share in the total household income. The average income per household was the highest in Nandigama followed by Kyasaram, Bhanoor, Pati, Ghanapur and Kardanur. The share of agriculture and allied sources income in the total household income was much higher in Kardanur ( $47 \%$ ) followed by Bhanoor ( $43 \%$ ), Kyasaram (41.1\%), Nandigama and Pati (37\%) and Ghanapur (36\%). Large area under profitable crops like maize, pigeonpea and vegetables have contributed to higher income in Bhanoor and Kyasaram as compared to other pilot site villages.

\subsubsection{Sources of water and utilization pattern}

The villages are getting water both from open and bore wells. Open wells have an average depth of $25 \mathrm{~m}$ with water table of $20 \mathrm{~m}$ whereas bore wells are tapping water from nearly $85 \mathrm{~m}$ depth with water table of $50 \mathrm{~m}$. Watershed belongs to hard rock aquifer and therefore has poor specific yield. Perched water table generally forms during the monsoon period in top $10-30 \mathrm{~m}$ depth and helps to recharge open wells. But most of the open wells do not retain water during post-monsoon period because of the depletion of groundwater level. Bore wells tap water from underlying layers of hard rock aquifer. Average area irrigated from each of the open or bore wells is about $1-1.5$ ha providing $4-5$ irrigations in a season. The average initial investment for bore wells is ₹19,000 with total investment of $₹ 77,000$ to date. The declining water table may not only raise the marginal operational cost but also give rise to a situation of diminished water availability, resulting in loss of farm output and decline in net returns.

\subsubsection{Perceptions about production problems and future interventions}

A large percentage of sample farmers in the villages felt that water scarcity particularly during 
crop production period is the major problem followed by lack of scientific information. Farmers opined that they can improve their net returns if credit is available at lower interest rates. With significant movement of rural labour from farm to nonfarm activities, labour scarcity has emerged as one of the burning constraints to agricultural production. This is again impacting their net returns as the farmers have to pay high wage returns during peak crop season.

Harvesting surplus runoff in dugout ponds and recycling the same for providing supplemental irrigation to rainy season crops or pre-sowing irrigation to rabi crops have proved to be the most successful technologies for adoption. Majority of farmers expressed need for farm ponds but are not willing to share their land for the same as nearly $60 \%$ of the farmers are small and medium farmers. Area grown under pigeonpea and vegetables almost occupies $26 \%$ of the cropped area under major crops. Farmers opined the need for availability of high-yielding varieties. Majority of farmers opined that nursery raising can be a sustainable livelihood option for youth. Farmers' perception about any developmental activity has to be prioritized and policy makers should design policies in order to reduce vulnerability of farmers to financial risk.

\subsection{Process}

\subsubsection{Partnerships}

The consortium approach is adopted to enhance the impact of integrated watershed management. The important partners in ICRISAT-led consortium were district administration, Watershed Department of Government of Telangana, Rural Education \& Agriculture Development (READ), a non-governmental organization (NGO) and community-based organizations. This project has adopted four principles: convergence; capacity building; collective action; and consortium for technical backstopping. Participatory research and development (PR\&D) was the key strategy to build the capacity of different stakeholders, namely community, NGO staff and line department staff. The PR\&D approach was also adopted for the integrated nutrient management (INM) and integrated pest management (IPM) trials considering the local resources to be used as sources of plant nutrients and for biopesticide production. All the PR\&D trials involved large number of farmers including small and marginal farmers. All the trials were conducted based on contributions in cash or kind by the participating farmers and efforts were made to involve as many farmers as possible during the project phase. In order to bring in transparency in the watershed development operations, participatory monitoring and evaluation approach was adopted along with the consortium partners. The community members were also involved in participatory groundwater monitoring as well as recording the yields from the PR\&D trials of INM, IPM and cultivar selection. Participatory monitoring and evaluation will be a continuous process to do mid-course corrections in the interventions as well as for the approach.

\subsubsection{Community mobilization}

\section{Watershed committee}

Gram sabhas (village meeting with farmers) were conducted to inform the community about watershed initiatives to improve livelihoods. ICRISAT team and resource person from NGO along with panchayat member participated in Gram sabhas to facilitate the formation of user groups (UGs). The approach of voluntary membership in the UGs was adopted to ensure sustainability. The UGs and existing self-help groups (SHGs) have representation on the decision-making body of the watershed, i.e. Watershed Committee. Each watershed village has one village-level committee (4-5 members) and from each village-level committee 2-3 members were appointed on executive committee for entire watershed.

The committee was constituted in an open meeting and the objectives were briefed clearly. The committee members and villagers were involved at each and every stage of project planning and execution of proposed interventions. For example, selection and construction of water harvesting sites and types of structure, procurement of the materials, record keeping, and verification of bills and payment delivery, etc. were handled by the Watershed Committee under the guidance of the consortium team. Transparency at every step established good rapport and resulted 
in large and active participation of the village community in watershed management and development.

\section{Inclusion of women}

For the success of watershed development programme and livelihood improvement, inclusion of women from the villages has prime importance. Importance of water conservation, once understood by women, may bring water literacy in the entire family. Judicious use of water for domestic needs is equally important as that in agriculture. In this project, the strength of women SHGs was harnessed through facilitation of the groups for different incomegenerating activities. Women were also actively involved in key watershed development activities, including construction of rainwater harvesting structures.

\subsubsection{Entry point activities}

Community participation for success of any research for development programme is very critical which to a large extent is affected by the initial actions/interventions in the programme. Thereby, introducing any programme to the community has always been a challenging and an important activity which is done through what are called 'entry point activities' (EPA). Studies indicate that knowledge-based rather than investment-focused EPAs to solve farmers' issues are more effective for rapport building and initiating collective action with the farmers for progressive development (Dixit et al., 2007). The main purpose of KBEPA is to build the sustainability and give a clear signal to the community that they should not be expecting dole-outs from the project for development of private farms. The important constraint which can provide tangible economic benefit to the community will be identified and implemented to build the trust and rapport with the community.

Soil health degradation is an important issue and studies show that most of the farmers are affected by it. As good soil health is a prerequisite to strengthen agri-based enterprises and this intervention fits well in the criteria of a good EPA. In this activity, farmers participated in collection of surface soil sample. Collected soil samples were analysed at ICRISAT Laboratory. Soil fertility status was shared with farmers through village level meeting during awarenessbuilding programmes and by writing the information on walls of common buildings. Further, soil fertility information was used to provide village-wise and crop-wise fertilizer recommendation. Moreover, with these recommendation demonstrations were conducted in farmers' field. In addition to soil fertility management, rainwater harvesting was also considered as EPA as water scarcity and depleted groundwater level were the key issues identified by the community.

\subsubsection{Dissemination}

Farmers in the villages are aware about the problems in agriculture, but they do not have complete information about crop production constraints and measures to alleviate these problems. For example, farmers understand that the yield of groundwater wells (bore/tube wells) was decreasing; however, they try to resolve this problem by digging another well or extending the depth of existing bore well. Another classic example is about fertilizer usage; farmers know the importance of fertilizer for crop growth but they do not understand that fertilizers are nutrient supplements in addition to available nutrients in the soil. Thus, fertilizer application should be done based on soil fertility status. In this watershed project, both traditional and innovative extension ways for information dissemination have been explored to improve the awareness and adoption rate among the farmers.

\section{Community programmes}

Publicity of watershed implementation programme among the targeted villages was the first priority in the project for getting full cooperation from the community. Thus, the project was formally launched on 21 October 2014 at Bhanoor village, Telangana in the presence of Joint Collector, Medak district, Commissioner, Rural Development, Telangana, President of Home Improvement, Supply Chain and IT, Asian Paints Limited, sarpanch of all watershed villages, Director, ICRISAT Development Center, other officials and community members, and senior officials of Asian 
Paints Limited (Fig. 6.2). During the launch programme, the work of check-dam construction was also inaugurated in the presence of dignitaries. Such small-scale functions were organized while initiating or inaugurating watershed activities; for example, seed distribution, soil health card distribution, the laying of foundation stones of rainwater harvesting structures, etc. These programmes have provided a good platform for awareness building and strengthening partnerships.

\section{Soil health cards}

In the context of soil health management, the key information dissemination tool was soil health cards. Soil health cards are customized information cards of soil fertility status and crop-wise fertilizer recommendation. This is one of the entry point activities, which built good relationship with the community. The soil health card (Fig. 6.3) has information about the farmer, location information of the farm,

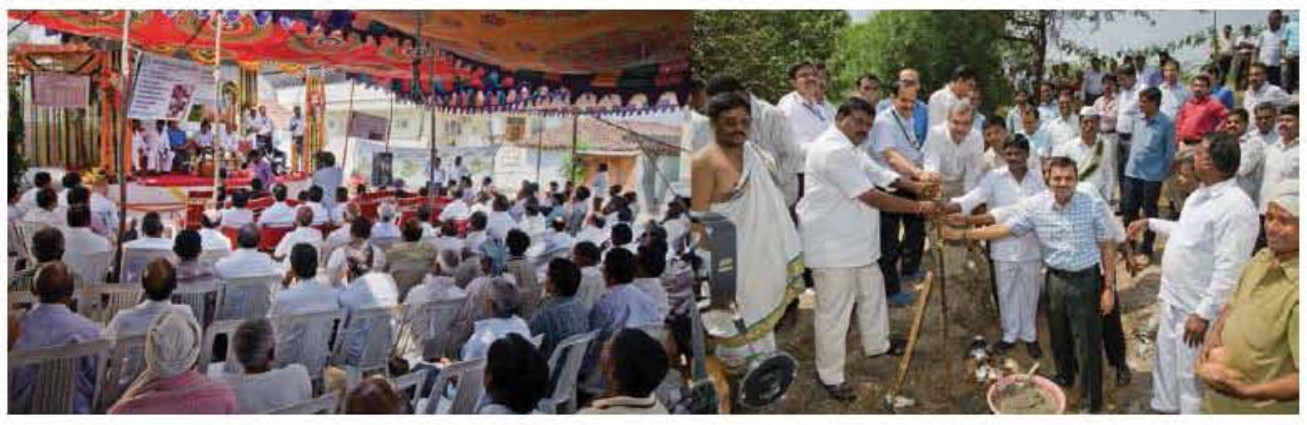

Fig. 6.2. Launch programme of Asian Paints Limited-ICRISAT watershed project in Bhanoor village.

\begin{tabular}{|c|c|c|c|}
\hline \multicolumn{4}{|c|}{ 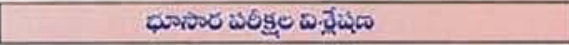 } \\
\hline So ostingor & steves & 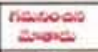 & - \\
\hline 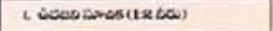 & & 8.76 & \\
\hline 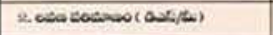 & $\infty$ & 0.69 & Asocosteres \\
\hline \multicolumn{4}{|l|}{ gos atimen } \\
\hline a. Sobat sojo (x) & os & 0.53 & Eist \\
\hline 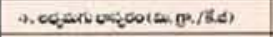 & 5 & 33.40 & 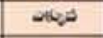 \\
\hline 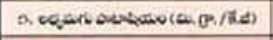 & $\infty$ & 230 & 200 \\
\hline \multicolumn{4}{|l|}{ 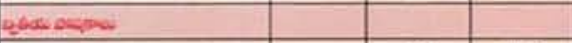 } \\
\hline 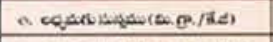 & 1000 & 3078 & $\sec \theta$ \\
\hline 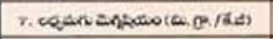 & 40 & 1737 & 20,0 \\
\hline 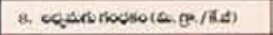 & 10 & 105.27 & anisos \\
\hline \multicolumn{4}{|l|}{ Hegenowic } \\
\hline 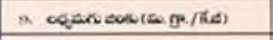 & 0.75 & 0.75 & \\
\hline 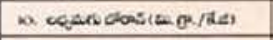 & 0.50 & 2.27 & ansos \\
\hline 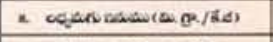 & 200 & 33.58 & ansos \\
\hline 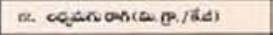 & es & 3.84 & oxisas \\
\hline 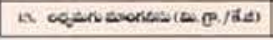 & 100 & 13.09 & ansos \\
\hline \multicolumn{4}{|c|}{ 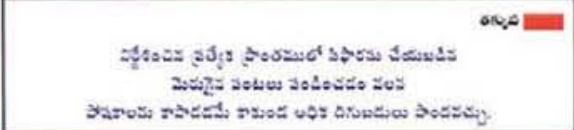 } \\
\hline
\end{tabular}

\begin{tabular}{|c|c|c|c|c|c|c|}
\hline \multicolumn{7}{|c|}{ 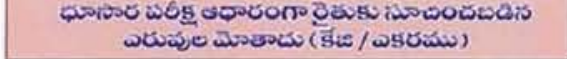 } \\
\hline$E^{\omega}$ & متلهain & 022 & dent & बरा & eotices & dor \\
\hline & Ueoa & DAP & MOP & Gypsum & $\mathrm{ZnSOA}$ & Boras \\
\hline $20(665)$ & 74 & 33 & 20 & 0.0 & 10.0 & 0.0 \\
\hline $20(0 t)$ & 89 & 39 & 20 & 0.0 & 10.0 & 0.0 \\
\hline$=2 \operatorname{ser} 2(6 b)$ & 176 & 39 & 25 & 0.0 & 10.0 & 0.0 \\
\hline Sots & 192 & 65 & 60 & 0.0 & 10.0 & 0.0 \\
\hline$\pi_{2}$ & 54 & 39 & 20 & 0.0 & 10.0 & 0.0 \\
\hline $5 w e x$ & 16 & 26 & 25 & 0.0 & 10.0 & 0.0 \\
\hline psodertu & 42 & 59 & 15 & 0.0 & 10.0 & 0.0 \\
\hline 208 & 246 & 39 & 40 & 0.0 & 10.0 & 0.0 \\
\hline$\infty$ & 159 & 39 & 40 & 0.0 & 10.0 & 0.0 \\
\hline $0 \leq 0$ & 179 & 98 & 75 & 0.0 & 10.0 & 0.0 \\
\hline$\sigma_{2}(s)$ & 51 & 26 & 15 & 0.0 & 10.0 & 0.0 \\
\hline Qg & 115 & 39 & 30 & 0.0 & 10.0 & 0.0 \\
\hline 360 orester & 4 & 33 & 0 & 0.0 & 10.0 & 0.0 \\
\hline$=-5 \% z_{2}(005)$ & 141 & 39 & 25 & 0.0 & 10.0 & 0.0 \\
\hline Axants & 11 & 39 & 20 & 0.0 & 10.0 & 0.0 \\
\hline 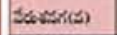 & 7 & 26 & 25 & 0.0 & 10.0 & 0.0 \\
\hline
\end{tabular}

Fig. 6.3. Customized soil health card prepared for farmers in watershed villages. 
status of major and micronutrients, and cropwise fertilizer recommendation for the major crops based on fertility status. The soil health card programme is also widely adopted by the Government of India for doubling the farmers' income.

\section{Wall writing}

Information related to soil fertility status has been also disseminated among the farmers through writing the information in Telugu (the local language) on the public walls in villages. This tool provides a wider dissemination channel, as all people from the village get access to this information. Although this information is not customized as per the crops or landholding, this tool has been also used in the watershed project for disseminating weather information and project details. Information written on the wall will be available for all farmers in the villages.

\subsubsection{Capacity development}

Every year, exposure to the visit-cum-training programme was organized for farmers from watershed villages (Fig. 6.4). The topics covered during this programme were integrated watershed management concept with improved land and water management, INM, improved crop management and practices IMP. Farmers visited the established model watershed where science-based farmer participatory consortium model for efficient management of natural resources for improving livelihoods of poor rural households was implemented by ICRISAT and its partners. Farmers have observed various interventions, including soil and water conservation measures, rainwaterharvesting structures, well recharging, improved crop varieties and cropping systems, crop diversification with high-value crops, productivity enhancement, livestock-based improvement and livelihood initiatives, and interacted with the local community. Farmers were impressed with the salient impacts that resulted due to the implementation of this model and appreciated the success due to collective action of the farmers in Kothapally village, Rangareddy district, Telangana and said that the visit provided an excellent learning opportunity.

\subsection{Interventions}

\subsubsection{Rainwater harvesting}

The excess rainwater taken out from the individual farms in a guided manner was stored at suitable sites. The potential sites for rainwater harvesting were identified by the village-level committee. The ridge to valley approach was followed for achieving equity and access to water. The site proposed for major water harvesting structures were technically evaluated by ICRISAT team of experts. Based on the technical evaluation, low-cost rainwater-harvesting structures such as farm ponds, loose boulder dams, check-dams, rock-filled dams, earthen check-dams, bore wells and open

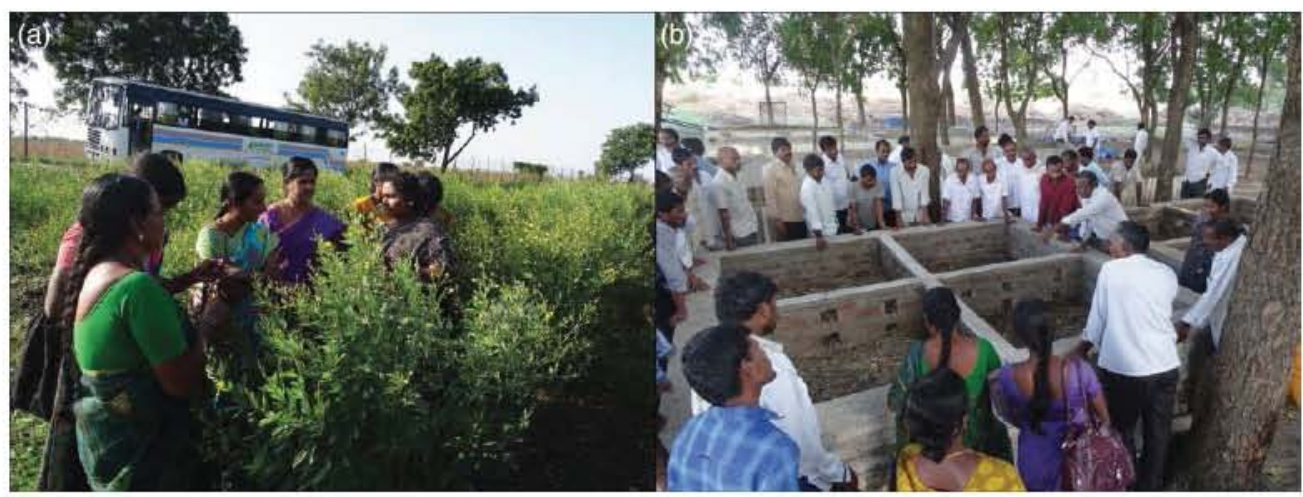

Fig. 6.4. Field visits of farmers from watershed villages to Kothapally (a) and ICRISAT campus (b). 
well recharging structures, etc. were established in the watershed (Table 6.4; Fig. 6.5). The lowcost structures are proven for sustainability, equity as well as cost-effectiveness. The impact of rainwater harvesting on water resources was evaluated by monitoring groundwater levels in existing bore well and monitoring the runoff at selected check-dams.

\subsubsection{Safe reuse of domestic wastewater for agriculture}

Safe use of wastewater could be a potential source of water. There are, however, numerous limitations for wastewater treatment and reuse in agriculture, such as a mismatch between demand and water supply, salinity, treatment capacity, over-application of nutrients, etc. We believe that the decentralized wastewater treatment (DWAT) system will address some of these problems and water scarcity issues at local scale. The rationale behind developing the DWAT system is water scarcity; the direct use of wastewater in agriculture is not good for farmers and consumers, disposal of untreated wastewater pollutes environment, and all localities do not have sewage treatment plants.

A wastewater treatment system has been established in Bhanoor village (Fig. 6.6). Domestic wastewater empties into a common drain that carries it to the end of the village. Few farmers were pumping this wastewater into their open wells and agricultural field, which is not advisable considering the harmful effect on farmers and consumers. Coupling wastewater treatment with the integrated watershed management

Table 6.4. Soil and water conservation structures in watershed villages in Patancheru mandal up to 2016.

\begin{tabular}{|c|c|c|c|c|c|c|c|}
\hline \multirow[b]{2}{*}{ Structure } & \multicolumn{6}{|c|}{ Number of structures } & \multirow{2}{*}{$\begin{array}{c}\text { Storage } \\
\text { capacity }\left(\mathrm{m}^{3}\right)\end{array}$} \\
\hline & Bhanoor & Pati & Kardanur & Kyasaram & Nandigama & Ghanapur & \\
\hline Check-dam & 3 & 1 & 1 & 3 & 2 & 1 & 12,700 \\
\hline Earthen check-dam & 0 & 0 & 0 & 0 & 0 & 1 & 1,200 \\
\hline Desiltation of check-dam & 2 & 0 & 0 & 0 & 0 & 2 & - \\
\hline Rock-filled dam & 1 & 0 & 0 & 0 & 2 & 0 & 430 \\
\hline Loose boulder dam & 14 & 0 & 7 & 12 & 40 & 0 & 5,100 \\
\hline Open well recharge pit & 9 & 0 & 0 & 7 & 0 & 0 & 12,700 \\
\hline Bore well recharge pit & 10 & 5 & 2 & 0 & 5 & 0 & 1,000 \\
\hline Farm pond & 4 & 0 & 0 & 1 & 0 & 0 & 1,000 \\
\hline Wastewater treatment & 1 & 0 & 0 & 0 & 0 & 0 & - \\
\hline
\end{tabular}

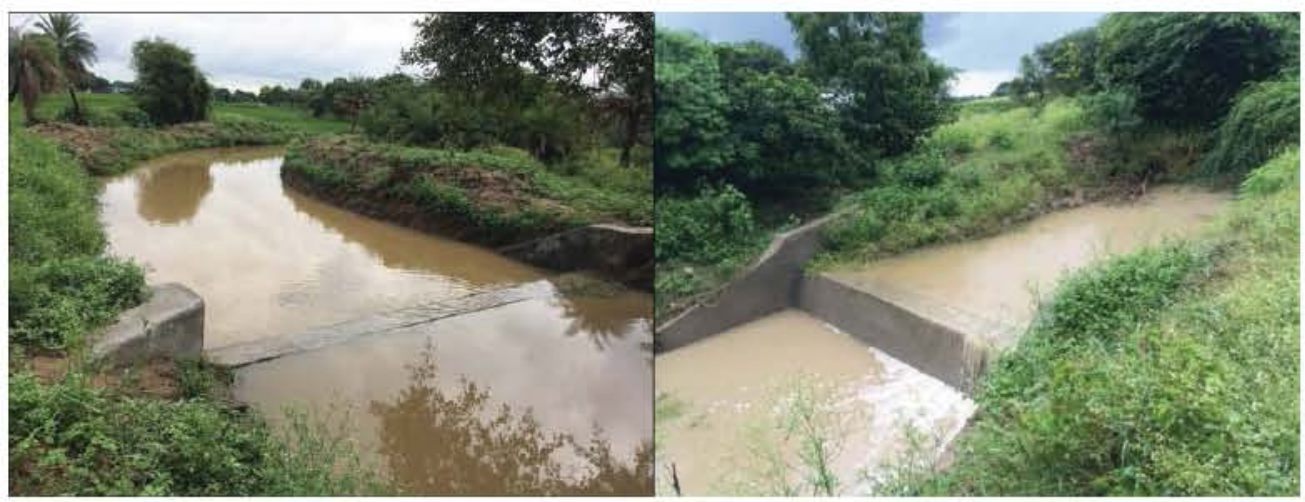

Fig. 6.5. Check-dam filled with water during the rainy season in September 2016 in Bhanoor village. 
programme is helpful in not only enhancing crop production and the income of smallholders but also improving the water quality of groundwater wells and downstream water bodies while partly addressing the issues of human health. Experts have visited the location and collected wastewater samples. The DWAT system is designed and constructed based on wastewater characteristics (see Box 6.1). Two types of vegetation, Typha latifolia and Canna indica, are transplanted in the constructed wetland. Now, wastewater flows through the wetland. After stabilization of the wetland, treated wastewater is available for irrigation. In addition, wastewater is safely disposed of without harming the environment.

\subsubsection{Improving crop productivity}

\section{Soil test-based fertilizer application}

A participatory demonstration of good agricultural practices was initiated with soil sampling as an entry point activity in watershed villages. Farmer participatory approach was followed for collecting soil samples from selected villages. Stratified soil sampling methodology was adopted for sampling (Sahrawat et al., 2008). The area was divided based on topography and cropping system. Farmers were trained for collecting soil samples from their fields. A total of 189 soil samples were collected and analysed for the selected villages. Analysis of the soil for macro- and
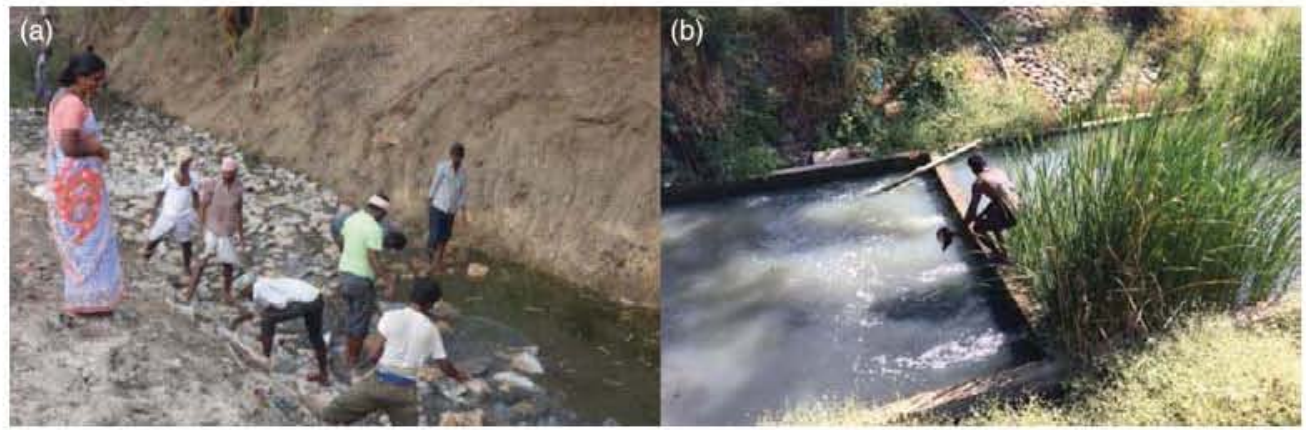

Fig. 6.6. Construction of wastewater treatment plant in Bhanoor village: (a) in progress; (b) completed structure.

Box 6.1. Design parameters for decentralized wastewater treatment system.

Number of households connected to common drainage $=700$

Domestic water consumption per household $=2001$ per day

Wastewater generation per household $(80 \%$ of consumption $)=160$ I per day

Total wastewater generation $=160 \times 700=112,000$ I per day $=112 \mathrm{~m}^{3}$ per day

Initial design hydraulic retention time (HRT) $=5$ days

Required volume of wetland considering 5 days HRT and 0.5 porosity $=\frac{112 \times 5}{0.5}=1120 \mathrm{~m}^{3}$

Available space for wetland: The wetland may be constructed into existing drain. Width of drain is $3-4 \mathrm{~m}$.

Bed of drain is $1-2 \mathrm{~m}$ below normal ground level.

Dimensions of constructed wetland: Width $=4 \mathrm{~m}$; depth $=1 \mathrm{~m}$; length $=280 \mathrm{~m}$.

Construction:

- As the required length of wetland is more, three phases are proposed to construct wetland. Based on the performance of first phase wetland, the design may be modified for remaining phases.

- One sedimentation tank $(3 \times 3 \times 3 \mathrm{~m})$ needs to be constructed for trapping solid waste flowing into drain.

- Walls on both sides of wetland along the length should be retained.

- Bottom face should be sealed by compaction or clay or cement concrete.

- Filter media: $80 \mathrm{~m}^{3}$ each of $40 \mathrm{~mm}$ gravel, $20 \mathrm{~mm}$ gravel, $10 \mathrm{~mm}$ gravel and coarse sand.

- Wetland plant species: Canna indica and Typha latifolia. 
micronutrients was completed at the ICRISAT laboratory. The soil analysis results indicated that soils of watershed villages are not deficient in phosphate and potash, but low organic carbon indicates low level of nitrogen $(\mathrm{N})$ in soil. In addition to major nutrients, soils are deficient in micronutrients. Out of the 189 soil samples collected from watershed villages, $62 \%, 35 \%$ and $19 \%$ soil samples were deficient in zinc, sulfur and boron respectively (Table 6.5). The geospatial maps for different soil parameters were prepared for watershed villages (Fig. 6.7).

The results of the soil analysis were distributed among farmers during a group meeting and crop-wise fertilizer recommendations were provided for each village. Soil test-based balanced fertilizer trials were conducted in famers' fields in selected villages to demonstrate the advantage of micronutrient application in addition to the application of N, phosphorus, and potassium fertilizers. Farmers applied $200 \mathrm{~kg}$ gypsum, $12.5 \mathrm{~kg}$ zinc sulphate and $2.5 \mathrm{~kg}$ borax per ha in improved practice compared with farmers' standard practice. The treatments were imposed on plots, side by side and uniform crop management practices were ensured in all the treatments. Application of all the nutrients except $\mathrm{N}$ was made as basal: $50 \%$ of $\mathrm{N}$ dose to non-legumes was added as basal and the remaining in two equal splits at one-month intervals.

\section{On-farm demonstrations}

The on-farm demonstrations of improved practices were carried out for maize and pigeonpea intercropping. During post-rainy season, chickpea trials were conducted along with another set of farmers. These demonstrations included improved cultivars, soil test-based nutrient application and IPM practices. In addition to micronutrient application, farmers were trained on IPM, for example, monitoring insect and pest incidence using pheromone traps (Fig. 6.8). Regular monitoring of insect and pest occurrence allows farmers to plan for plant protection measures before any major damage to crop, and thus save crop loss. To ensure nutritional diet to families, concept of kitchen garden was also implemented in the villages. Under this activity, a small quantity of seeds of different vegetables were distributed to women farmers. Depending upon the availability of space, farmers have grown the vegetables near their house or on farm bunds.

\section{Kitchen garden}

To address the issue of malnutrition in children and women to some extent there is a need to promote sustainable kitchen gardens for effective utilization of available natural resources like water and land by using organic farming methods as well as to improve diet by inclusion of fresh and safe nutritious vegetables produced in kitchen gardens. By taking up this activity, school children will gain hands-on experience in some areas of the school curriculum (e.g. science, agriculture, environmental science and home economics) as well as developing an understanding of nature. Kitchen garden kits consisting of different vegetable seeds like tomato, brinjal, okra, amaranth, spinach, bottle gourd and bitter gourd were distributed to women SHGs, and primary and high school children in the watershed villages. A total of 150 vegetable kits were distributed to school children and SHGs. Women grew the vegetables in their backyards and harvested the vegetables, which were used for their own family consumption.

Table 6.5. Percentages of soil samples deficient in macro- and micronutrients in watershed villages.

\begin{tabular}{lcccccc}
\hline Village & $\begin{array}{c}\text { Organic } \\
\text { carbon }\end{array}$ & $\begin{array}{c}\text { Available } \\
\text { phosphorus }\end{array}$ & $\begin{array}{c}\text { Available } \\
\text { potassium }\end{array}$ & $\begin{array}{c}\text { Available } \\
\text { sulfur }\end{array}$ & $\begin{array}{c}\text { Available } \\
\text { zinc }\end{array}$ & $\begin{array}{c}\text { Available } \\
\text { boron }\end{array}$ \\
\hline Bhanoor & 33 & 9 & 0 & 36 & 51 & 20 \\
Ghanapur & 52 & 13 & 0 & 26 & 58 & 13 \\
Kardanur & 59 & 5 & 0 & 41 & 50 & 18 \\
Kyasaram & 79 & 9 & 0 & 30 & 76 & 30 \\
Nandigama & 67 & 17 & 0 & 44 & 94 & 17 \\
Pati & 73 & 8 & 0 & 40 & 60 & 13 \\
Average & 59 & 10 & 0 & 35 & 62 & 19 \\
\hline
\end{tabular}



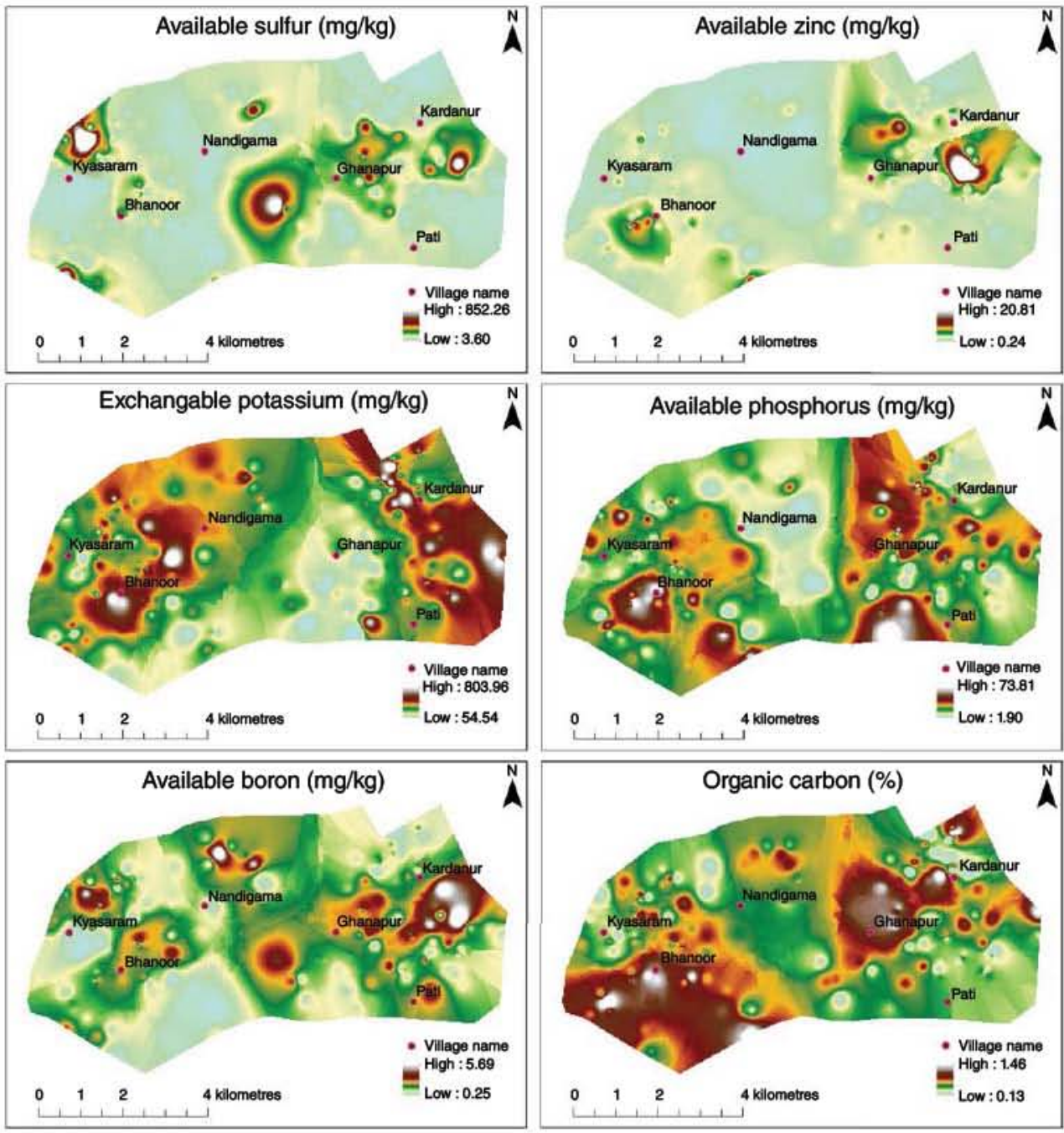

Fig. 6.7. Soil fertility maps based on stratified soil samples from watershed villages.

\section{Promoting organic manure}

Soils are degraded due to low levels of organic carbon, which is critical for the physical, chemical and biological processes indicative of soil fertility and soil health. Vermicomposting units were established for recycling farm waste. In addition, Gliricidia saplings were transplanted on community land and will be a rich source of green manure in future. These saplings were grown by SHGs from watershed villages that also provided additional income to SHG members. In total, 5500 saplings were grown in the nursery by SHGs in five villages.

\section{Income-generating activity: spent malt-based business model}

Spent malt is one of the byproducts generated from the brewery. It consists of malt residues and grain which contains carbohydrates, proteins and lignin, and water-soluble vitamins and is used as animal feed. It is palatable and is readily consumed by animals. In Bhanoor village, the spent malt unit was started by Mrugasheela SHG with 37 beneficiaries. The SHG group sold 354 tons of spent malt during 25 months till February 2017 and earned a net benefit of ₹ 75,611 after deducting all the expenditure costs, such as 
transportation, maintenance, equipment and labour charges (Table 6.6). Similarly, in Kyasaram village, the spent malt unit was started by Sri Bhavani SHG with 36 beneficiaries. The group sold 438 tons and earned a net benefit of ₹85,360. This business model of spent malt establishment in the villages helped in improving and strengthening the SHG group's capital and also the financial status of the group members due to the profits gained with spent malt. Moreover, farmers have also observed at least $1 \mathrm{l}$ increase in milk production per animal due to feeding of spent malt.
Similar activities have been initiated in Nandigama village targeting 20 beneficiary farmers with $250 \mathrm{~kg} /$ day of spent malt feeding 90 milch animals.

\subsection{Sustainability}

\subsubsection{Increased yield}

On-farm demonstrations of improved practices were carried out for maize, pigeonpea and chickpea

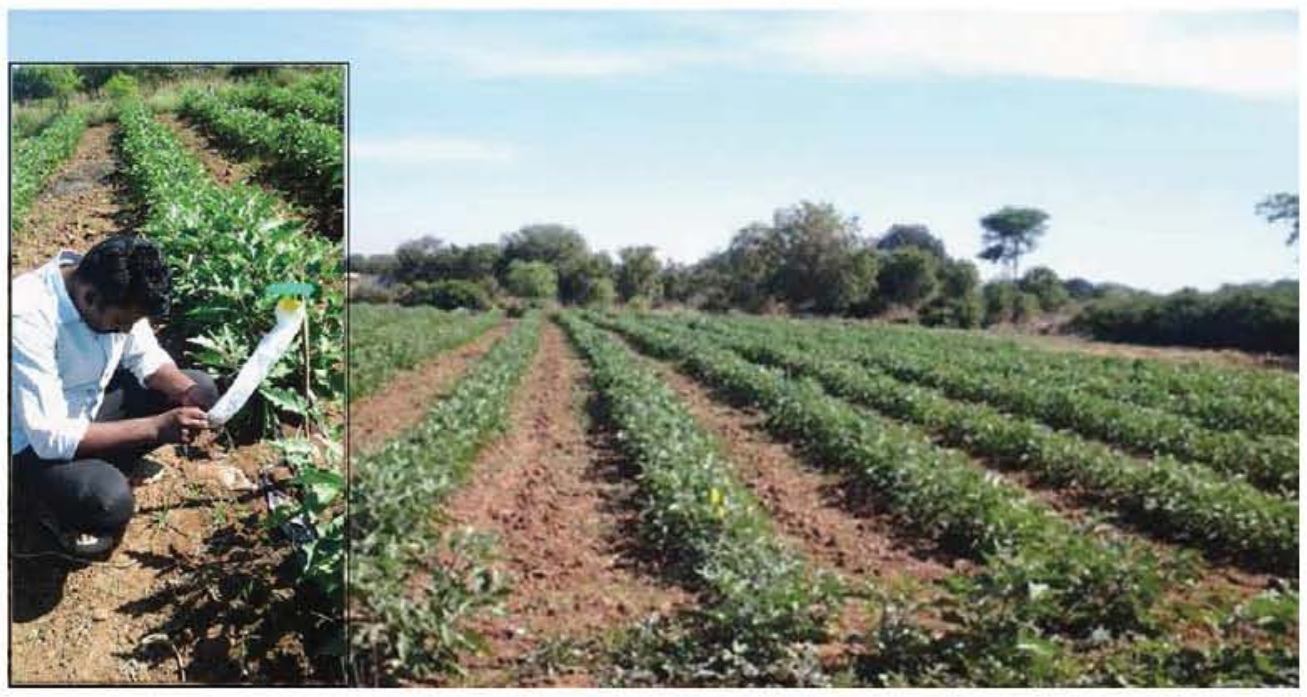

Fig. 6.8. Brinjal field in Bhanoor village; (inset) a farmer using a pheromone trap to monitor insect and pest incidence.

Table 6.6. Increased milk yield and income in Bhanoor and Kyasaram villages due to use of spent malt as animal feed (the 25 months up to February 2017).

\begin{tabular}{lrr}
\hline Particulars & Bhanoor & Kyasaram \\
\hline Self-help group & Mrugasheela Sri Bhavani \\
Number of farmers & 37 & 46 \\
Number of cattle (feeding) & 177 & 292 \\
Average use of spent malt in the village (kg/day) & 860 & 1,380 \\
Milk production in the village (I/day) & 960 & 1,180 \\
Increase in milk production by feeding spent malt (l/animal/day) & 1 & 1 \\
Increase in gross income due to spent malt (₹/day/village) & 8,550 & 15,280 \\
Increase in net income due to spent malt (₹/day/village) & 4,670 & 9,070 \\
Increase in family average net income due to proposed intervention (₹/family/ & 3,780 & 5,910 \\
$\quad$ month) & 354 & 438 \\
Spent malt sold by the SHG (cumulative) (tons) & 75,611 & 85,360 \\
Net profit to SHG (cumulative) (₹) & &
\end{tabular}


crops. A total of 50 demonstrations were conducted for maize, pigeonpea and chickpea crops with improved cultivars and micronutrients. The observed data of crop-cutting experiments indicated up to $31 \%, 50 \%$ and $37 \%$ increase in grain yield of maize, pigeonpea and chickpea respectively for improved management practices (Fig. 6.9).

\subsubsection{Increased water availability}

Precise measurement of the water column depth in the check-dam was done by using a pressure transducer (Diver, make: Schlumberger Water Services, model-DI501) that was kept in the stilling well (constructed at the upstream side of the check-dam). Watershed villages received good amount of rainfall during September and October 2016 that resulted in high runoff leading to overflow of check-dams. Daily records of water column in check-dam obtained from diver and daily rainfall data from the weather station are shown in Fig. 6.10. The process to estimate the number of fillings of check-dam is presented in Table 6.7. The estimated infiltration rate was $19.1 \mathrm{~cm} /$ day. Total evaporation during the time when water was available in the check-dam was $12.9 \mathrm{~cm}$. The total number of fillings was 7.2. Thus, total water infiltrated from the check-dam was 7.2 times the storage capacity of the check-dam. Similar number of fillings was assumed for remaining checkdams to estimate amount of water infiltrated in the ground. The total estimated groundwater recharge from the check-dams was about $91,400 \mathrm{~m}^{3}$.

Groundwater levels were monitored in eight selected bore wells near check-dams using water-level indicator. The difference of groundwater levels during July and August was very less due to less amount of rainfall during this period. The heavy rainfall event occurred in the first week of September, which led to increase in groundwater table by 3-32 m (below ground level) during October (Fig. 6.11). Among these bore wells, those near check-dam in Bhanoor village showed highest rise in water table from $38 \mathrm{~m}$ in August to $21 \mathrm{~m}$ in September and $8 \mathrm{~m}$ in October (Fig. 6.11).

\subsection{Way Forward}

Scaling-up of the resource conservation technologies implemented in this watershed project to resource-poor and water-scarce rainfed agriculture will help to achieve the sustainable

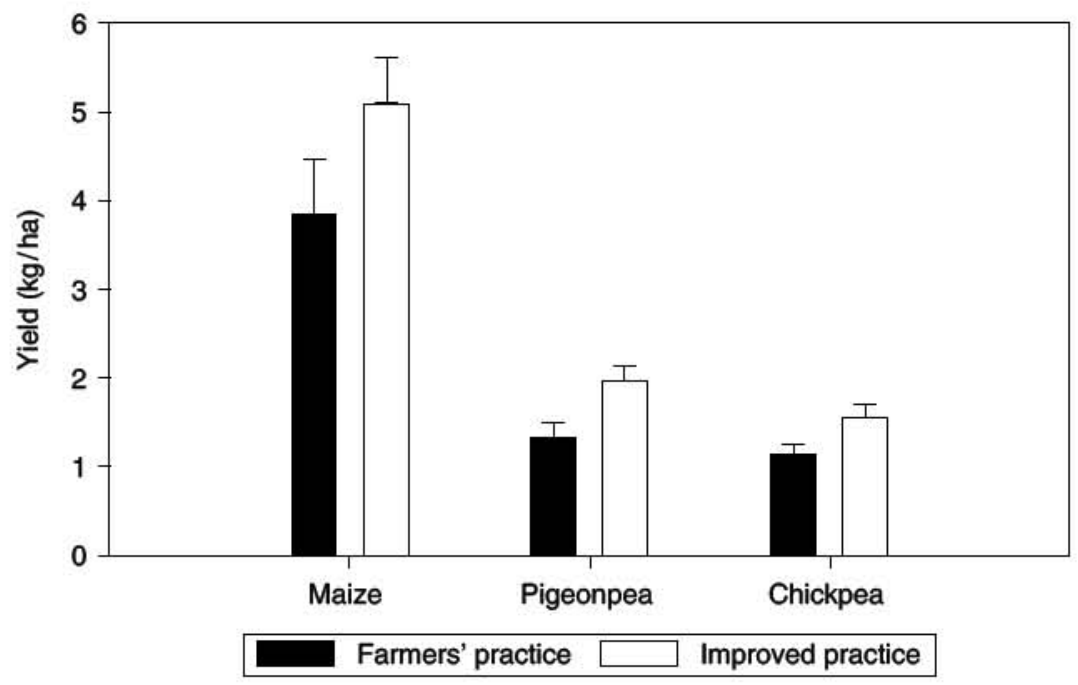

Fig. 6.9. Comparing standard farmers' practice with improved management practice for grain yield of three crops, 2016. 


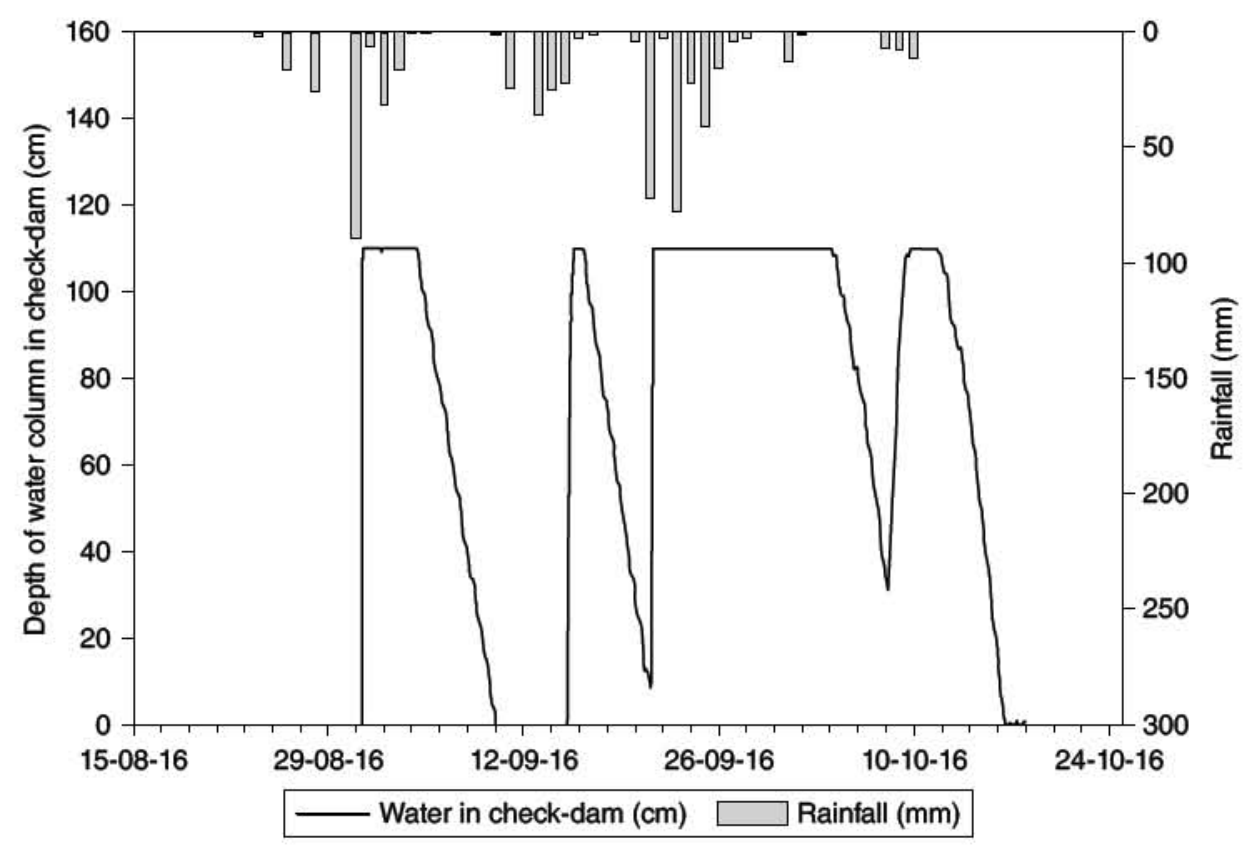

Fig. 6.10. Observed rainfall and runoff depth during the 2016 monsoon period.

Table 6.7. Process to estimate number of fillings of check-dam from well logger data in Bhanoor village.

\begin{tabular}{|c|c|c|}
\hline Item & Method & Value \\
\hline $\begin{array}{l}\text { Maximum depth of water } \\
\text { column }(\mathrm{cm})(\mathrm{A})\end{array}$ & - & 110 \\
\hline $\begin{array}{l}\text { Time to deplete water from } \\
\text { full capacity to zero level } \\
\text { (days) (B) }\end{array}$ & $\begin{array}{l}\text { From well } \\
\text { logger }\end{array}$ & 5.8 \\
\hline Infiltration rate $(\mathrm{cm} /$ day) $(\mathrm{C})$ & $A / B$ & 19.1 \\
\hline $\begin{array}{l}\text { Number of days of water } \\
\text { available in check-dam } \\
\text { (D) }\end{array}$ & $\begin{array}{l}\text { From well } \\
\text { logger }\end{array}$ & 41.3 \\
\hline $\begin{array}{l}\text { Total evaporation during } \\
\text { days of water available in } \\
\text { check-dam }(\mathrm{cm})(\mathrm{E})\end{array}$ & $\begin{array}{l}\text { From pan } \\
\text { evaporimeter }\end{array}$ & 12.9 \\
\hline $\begin{array}{l}\text { Total depth of water } \\
\text { infiltrated in check-dam } \\
(\mathrm{cm})(\mathrm{F})\end{array}$ & $C \times D$ & 788.8 \\
\hline Number of fillings $(G)$ & F/A & 7.2 \\
\hline
\end{tabular}

development goals of zero hunger and reduced poverty. The learning from this project will be utilized to implement the technologies in upcoming watershed projects. For example, in the earlier project, ICRISAT in consultation with
SABMiller had initiated provision of supplying spent malt from The Charminar breweries to Fasalvadi village ( $40 \mathrm{~km}$ from Bhanur) with the aim of strengthening livelihood opportunities and financial security of the women's SHG by increasing milk yield and fat content since December 2011. Based on the success of pilot study, the activity was extended to another watershed area nearby at Kothapally. Similar activity is extended to Asian Paints LimitedICRISAT watershed.

\section{Acknowledgements}

Authors acknowledge Asian Paints Limited for providing the funding support for implementing the watershed project, READ as an implementation partner, the village level watershed committee, SHGs and farmers for active participation in watershed activities, Mr D.S. Prasad Rao (ICRISAT) for coordinating the activities with village community, Mr Satya Vagu (ICRISAT) and $\mathrm{Mr}$ Mallesham (ICRISAT) for assisting in watershed project, and Dr VenkatRadha for developing soil fertility maps. 


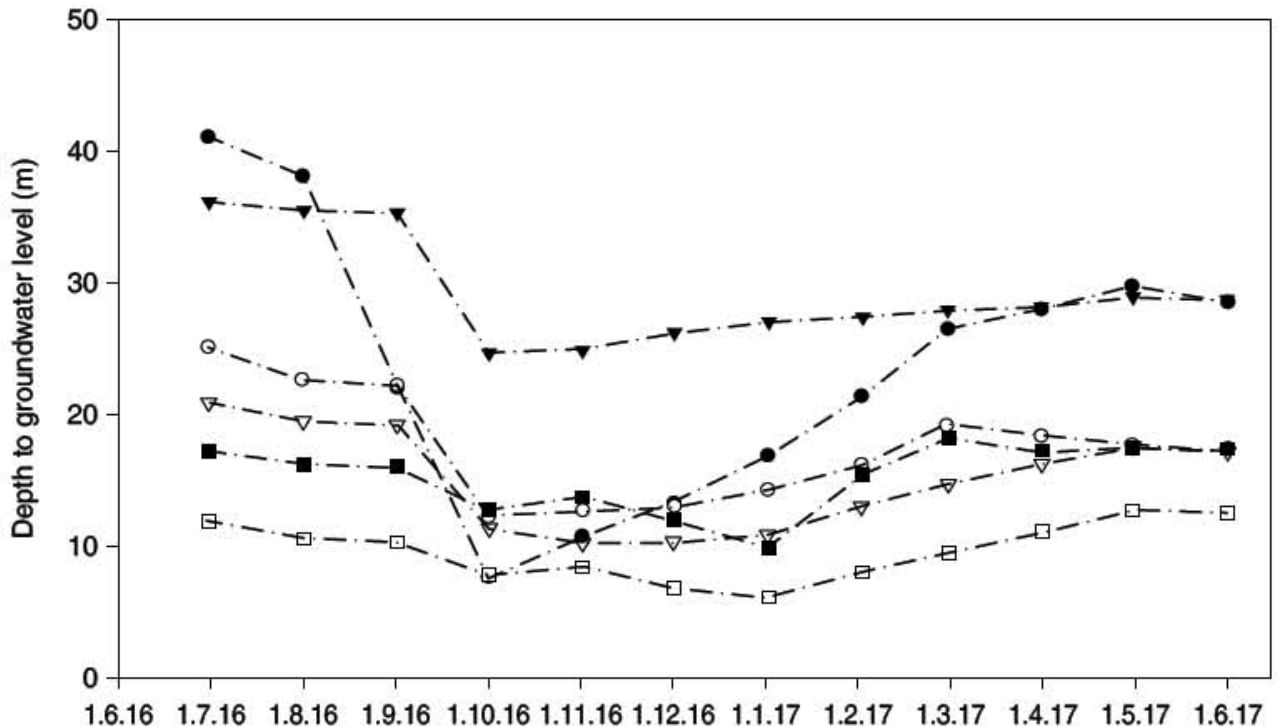



Fig. 6.11. Increase in groundwater level (decrease in depth to groundwater) observed in selected bore wells located near the check-dams in project villages, 2016-2017.

\section{References}

Dixit, S., Wani, S.P., Rego, T.J. and Pardhasaradhi, G. (2007) Knowledge-based entry point and innovative up-scaling strategy for watershed development projects. Indian Journal of Dryland Agriculture and Development 22(1), 22-31.

Gram Panchayats of respective villages (2015) Statistical abstract of Bhanur, Pati, Ghanapur, Nandigama, Kysaram, and Kardanur Gram panchayats, Patancheru Mandal, Sangareddy District, Telangana State, India.

Mandal Panchayat of Patancheru mandal (2015) Statistical abstract of Patancheru Mandal, Sangareddy District, Telangana State, India.

Sahrawat, K.L., Rego, T.J., Wani, S.P. and Pardhasaradhi, G. (2008) Stretching soil sampling to watershed: evaluation of soil-test parameters in a semi-arid tropical watershed. Communications in Soil Science and Plant Analysis 39, 2950-2960.

Wani, S.P., Singh H.P., Sreedevi, T.K., Pathak, P., Rego et al. (2003) Farmer-participatory integrated watershed management: Adarsha watershed, Kothapally, India, an innovative and upscalable approach. A case study. In: Harwood, R.R. and Kassam, A.H. (eds) Research Towards Integrated Natural Resources Management: Examples of Research Problems, Approaches and Partnerships in Action in the CGIAR. Interim Science Council, Consultative Group on International Agricultural Research, Washington, DC, pp. 123-147.

Wani, S.P., Sreedevi, T.K., Reddy, T.S.V., Venkateswarlu, B. and Prasad, C.S. (2008) Community watersheds for improved livelihoods through consortium approach in drought prone rainfed areas. Journal of Hydrological Research and Development 23, 55-77.

Wani, S.P., Sreedevi, T.K., Rockström, J. and Ramakrishna, Y.S. (2009) Rainfed agriculture - past trends and future prospects. In: Wani, S.P., Rockström, J. and Oweis, T. (eds) Rainfed Agriculture: Unlocking the Potential. Comprehensive Assessment of Water Management in Agriculture Series. CAB International, Wallingford, Oxfordshire, pp. 1-35. 